\title{
Evaluation of Pearl Millet Grain Hybrids for Resistance to Meloidogyne spp. and Leaf Blight Caused by Pyricularia grisea
}

\author{
P. Timper, J. P. Wilson, A. W. Johnson, and W. W. Hanna, USDA ARS, Coastal Plain Experiment Station, P.O. \\ Box 748, Tifton, GA 31793
}

\begin{abstract}
Timper, P., Wilson, J. P., Johnson, A. W., and Hanna, W. W. 2002. Evaluation of pearl millet grain hybrids for resistance to Meloidogyne spp. and leaf blight caused by Pyricularia grisea. Plant Dis. 86:909-914.

Pearl millet, Pennisetum glaucum, has potential as a grain crop in the southeastern United States. Our objectives were to (i) determine the resistance and/or tolerance of pearl millet hybrids to Meloidogyne incognita race 3 and $M$. arenaria race 1; (ii) compare reproduction of Meloidogyne spp. on pearl millet and corn; and (iii) determine the disease severity of leaf blight caused primarily by Pyricularia grisea. In a field naturally infested with $M$. incognita, experimental pearl millet hybrids with inbreds 114 and 117 as the pollinators had fewer numbers of second-stage juveniles and more severe leaf blight than did HGM-100, a nematode-susceptible hybrid; hybrids with inbred 115 as the pollinator were similar to HGM-100 in both nematode numbers and foliar disease severity. Grain yields in pearl millet were greater in plots treated with 1,3-dichloropropene than in control plots and were negatively correlated with leaf blight severity. In a greenhouse experiment, both $M$. incognita and $M$. arenaria produced fewer eggs on pearl millet hybrids with pollinators 114, 117, 101, 102, and 103 than on hybrid HGM-100. Reproduction of $M$. incognita was less on the resistant pearl millet hybrids than on corn. Because both $M$. incognita and $P$. grisea can reduce grain yield of pearl millet, hybrids developed for the southeastern United States should be resistant to both pathogens.
\end{abstract}

Additional keywords: Paratrichodorus sp., root-knot nematodes, stubby-root nematode

Pearl millet, Pennisetum glaucum, has potential as a grain crop in the southeastern United States. Although it is used as a food grain in India and Africa, its primary use in the United States is high quality feed for poultry and livestock $(1,6,15)$. Hybrids adapted to the southeast should be high yielding, resistant to the rust fungus $P u c$ cinia substriata var. indica, and early maturing. The two latter characteristics allow growers greater flexibility in planting date (May to July). In addition, pearl millet tolerates drought and low fertility conditions, thus requiring few irrigation and fertilizer inputs and is resistant to preharvest aflatoxin contamination $(13,14,17)$.

To be compatible in rotation with other crops grown in the southeast, pearl millet hybrids should not increase soilborne pathogens of plants including nematodes. Root-knot nematodes, Meloidogyne spp., are major pests of cotton, peanut, and vegetable crops in this region because of the long growing season and sandy soils. Corn (Zea mays) is commonly grown in

Corresponding author: P. Timper

E-mail: ptimper@tifton.cpes.peachnet.edu

Accepted for publication 22 April 2002.

Publication no. D-2002-0620-01R

This article is in the public domain and not copyrightable. It may be freely reprinted with customary crediting of the source. The American Phytopathological Society, 2002. rotation with cotton (Gossypium hirsutum) and peanut (Arachis hypogaea); however, corn is not a compatible rotation crop for cotton in fields infested with Meloidogyne incognita because it is a good host for reproduction of this nematode $(4,19)$.

Pearl millet hybrids vary in susceptibility to Meloidogyne spp. For example, 'Gahi 1' supported reproduction of $M$. incognita and $M$. javanica, but not $M$. arenaria; whereas, 'Gahi 3' was resistant to reproduction of all three species (9). In a field study, numbers of $M$. incognita increased over the growing season in soil planted to the hybrid HGM-100, but did not reduce yields suggesting some level of tolerance to nematode damage in this hybrid (10).

The primary objectives of this study were to determine the resistance and/or tolerance of experimental pearl millet hybrids to $M$. incognita race 3 and $M$. arenaria race 1 , and to compare the suitability of pearl millet as a host relative to corn. Resistance describes the effect of the plant on nematode reproduction, while tolerance describes the amount of host injury or yield loss from nematode infection (2). A secondary objective was to determine the severity of leaf blight, which is caused by a complex of fungal pathogens (18), because little is known about the effect of this disease on grain yield of pearl millet in the southeastern United States. In this region, Pyricularia grisea is the primary pathogen causing leaf blight on pearl millet (18). The hybrid HGM-100 is resistant to $P$. grisea (5); however, the reaction of the experimental hybrids is unknown. A preliminary report on this research was previously published (11).

\section{MATERIALS AND METHODS}

Field Experiment. The study was initiated in 1997 on the Gibbs Farm at the Coastal Plain Experiment Station, Tifton, GA. The soil was a Tifton loamy sand (fine-loamy, siliceous thermic Plinthic Kandiudults: $85 \%$ sand, $10 \%$ silt, $5 \%$ clay, $0.5 \%$ organic matter). The experiment was a split-plot design with pearl millet hybrids as the main plot and nematicide treatment as the subplot. The nematicide was used to assess tolerance of the hybrids to nematode damage. There were 14 pearl millet hybrids; the Meloidogyne-susceptible hybrid HGM-100, and 13 experimental hybrids produced by crossing sister lines of Tift $99 \mathrm{~A}_{1}$ (W. Hanna, unpublished) with one of three inbred male pollinators designated 114, 115, and 117. Main plots consisted of two soil beds; one treated with the nematicide 1,3-dichloropropene (1,3-D) and one untreated control. Treatments were replicated five times in a field naturally infested with $M$. incognita.

A fall-planted cover crop of hairy vetch (Vicia villosa) was grown in 1997 and 1998. Prior to application of 1,3-D, the soil was disc-harrowed, 5-10-15 (N-P-K) fertilizer was broadcast at $280 \mathrm{~kg} / \mathrm{ha}$, turned to a depth of 25 to $30 \mathrm{~cm}$ with a moldboard plow, and shaped into beds $6.1 \mathrm{~m}$ long and $1.8 \mathrm{~m}$ wide. Replications (blocks) were separated by $3-\mathrm{m}$ alleys. The nematicide 1,3-D was injected $20 \mathrm{~cm}$ deep at 51.1 liters/ha through a single chisel in one row per plot and bedded on 24 June 1998 and 26 May 1999. Soil temperatures at time of 1,3-D application were 28 and $25^{\circ} \mathrm{C}$ at a 15 cm depth in 1998 and 1999, respectively. Approximately $1.3 \mathrm{~cm}$ of irrigation water was applied to all plots immediately after nematicide application to seal the soil surface and enhance efficacy of the fumigant. To control weeds, plots were rotary tilled to a depth of 8 to $10 \mathrm{~cm}$ in 1998 or were sprayed with glyphosate at $1.1 \mathrm{~kg}$ a.i./ha in 19991 to 2 days before planting hybrids. Pearl millet hybrids (Table 1) were seeded 8 July 1998 and 9 June 1999 at $3.2 \mathrm{~kg}$ seeds per ha in two rows $0.9 \mathrm{~m}$ apart on the bed. Hybrids were planted in the same plots in both years. Immediately after planting, plots were sprayed with the herbicide propazine at $1.1 \mathrm{~kg}$ a.i./ha and irri- 
gated with approximately $1.3 \mathrm{~cm}$ water. Atrazine was applied at $0.8 \mathrm{~kg}$ a.i./ha 12 and 20 days after planting to control weeds in 1998 and 1999, respectively. The plots were cultivated and side-dressed with 168 $\mathrm{kg} / \mathrm{ha}$ ammonium nitrate $(34 \% \mathrm{~N}) 31$ and 33 days after planting in 1998 and 1999, respectively. Insecticides were applied in 1998 to control the corn earworm (Heli- coverpa zea), but were not necessary in 1999.

Soil samples for nematode densities were collected 9 July and 8 October in 1998 and 10 June and 21 September in 1999. Samples consisted of 10 soil cores $(2.5 \mathrm{~cm}$ diameter $\times 25 \mathrm{~cm}$ deep) collected from each row of a subplot. Each sample was thoroughly mixed, and nematodes

Table 1. Soil densities of Meloidogyne incognita second-stage juveniles (J2) at planting (Pi) and after harvest $(\mathrm{Pf})$ of pearl millet hybrids during two growing seasons in plots not treated with 1,3dichloropropene

\begin{tabular}{|c|c|c|c|c|}
\hline \multirow[b]{3}{*}{ Hybrid } & \multicolumn{4}{|c|}{ M. incognita $\left(\mathrm{J} 2 / 150 \mathrm{~cm}^{3}\right)^{\mathrm{a}}$} \\
\hline & \multicolumn{2}{|c|}{1998} & \multicolumn{2}{|c|}{1999} \\
\hline & $\mathbf{P i}$ & Pf & $\mathbf{P i}$ & $\mathbf{P f}$ \\
\hline HGM-100 & 20 & 142 & 1,202 & 1,158 \\
\hline $107 \times 115$ & 34 & 232 & 812 & $382 * \mathrm{~b}$ \\
\hline $109 \times 115$ & 12 & 48 & 612 & 1,230 \\
\hline $111 \times 115$ & 4 & 226 & 606 & 1,182 \\
\hline $112 \times 115$ & 16 & 74 & 658 & 1,666 \\
\hline $113 \times 115$ & 10 & 172 & 908 & 672 \\
\hline $111 \times 114$ & 2 & 32 & $312 *$ & $10 *$ \\
\hline $112 \times 114$ & 8 & 32 & $352 *$ & $260 *$ \\
\hline $113 \times 114$ & 10 & 28 & $200 *$ & $38 *$ \\
\hline $106 \times 117$ & 6 & 26 & $498 *$ & $50 *$ \\
\hline $108 \times 117$ & 18 & 26 & $522 *$ & $112 *$ \\
\hline $109 \times 117$ & 18 & 18 & $352 *$ & $120 *$ \\
\hline $111 \times 117$ & 10 & 40 & $290 *$ & $150 *$ \\
\hline $112 \times 117$ & 12 & 44 & $362 *$ & $48^{*}$ \\
\hline
\end{tabular}

a Soil samples collected 9 July (Pi) and 8 October (Pf) 1998, 10 June (Pi) and 21 September (Pf) 1999. Nematode densities are the mean of five replicates from control plots (not treated with the nematicide 1,3-dichloropropene).

${ }^{\mathrm{b}}$ Densities of $M$. incognita within a column followed by an asterisk are different from HGM-100 ( $P$ $\leq 0.05$ ).

were extracted from a $150-\mathrm{cm}^{3}$ subsample by centrifugal flotation (8). Severity of leaf blight was visually estimated as the percentage of foliage infected, chlorotic, or necrotic on 28 August 1998 and 17 August 1999. Two ratings were performed, one on each side of the subplot, and the percentages were averaged.

After pollination, 15 grain heads per plot were bagged to prevent bird damage. Bagged heads were harvested, dried in a forced-air oven $\left(38^{\circ} \mathrm{C}\right)$ for 4 days, and machine-threshed. Grain yield was determined by multiplying the average seed weight per head by the total heads per plot.

Greenhouse experiment. The objective of this experiment was to determine reproduction of $M$. incognita race 3 and $M$. arenaria race 1 on pearl millet and corn hybrids. Eight experimental pearl millet hybrids were tested (Fig. 1). These hybrids were derived from crossing sister lines of Tift $99 \mathrm{~A}_{1}$ with one of five male pollinators designated 101, 102, 103, 114, and 117. The pearl millet hybrid HGM-100 was used as a susceptible control. The two corn hybrids, Dekalb 683 and Pioneer 3146, are resistant and susceptible to $M$. arenaria, respectively (4). Two to four seeds of each hybrid were planted in $15-\mathrm{cm}$-diameter pots filled with approximately 1.5 liter of loamy sand ( $85 \%$ sand, $11 \%$ silt, $4 \%$ clay, $\mathrm{pH}$ 5.3) that had been steam heated at $100^{\circ} \mathrm{C}$ for $6 \mathrm{~h}$ prior to use. Seedlings were thinned to one plant per pot after germina-

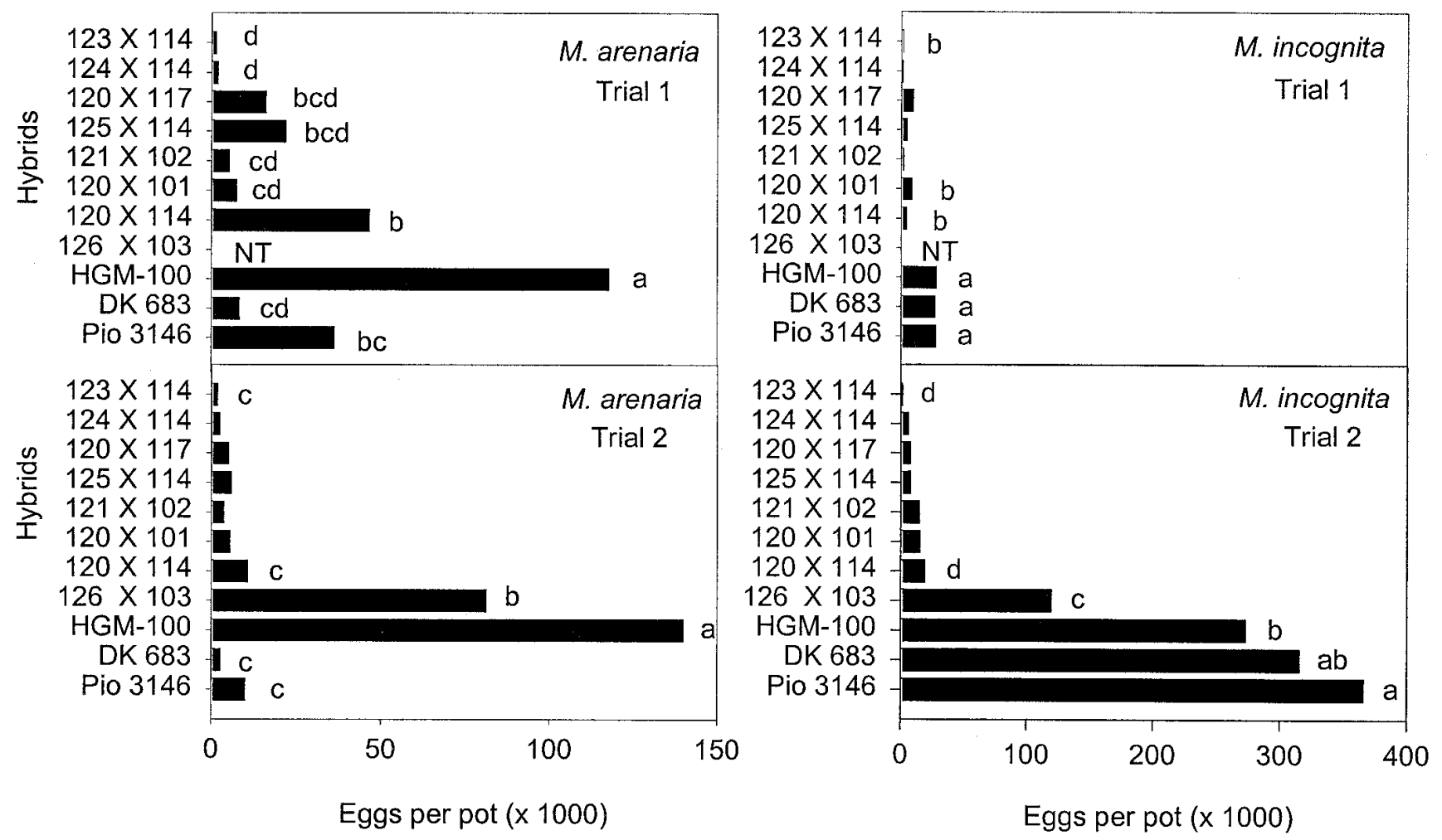

Fig. 1. Reproduction of $M$. arenaria race 1 and Meloidogyne incognita race 3 on pearl millet and corn hybrids (DeKalb 683 and Pioneer 3146 ) in two greenhouse trials. Pots were inoculated with 8,000 eggs of $M$. incognita or $M$. arenaria. Nematode eggs were extracted from roots 58 to 60 days later. Bars are the means of seven replicates. Bars within a graph with the same letter are not different $(P>0.05)$. Pearl millet hybrid HGM-100 was the nematodesusceptible control. Because of poor germination, hybrid $126 \times 103$ was not tested (NT) in Trial 1 . 
tion and a slow release fertilizer (14-14-14) was applied. Nematode eggs were extracted from roots of tomato (Lycopersicon esculentum, 'Rutgers') with $0.5 \% \mathrm{NaOCl} 1$ to $2 \mathrm{~h}$ before inoculating an experiment (7). Pearl millet and corn plants were inoculated with 8,000 eggs of either $M$. incognita or $M$. arenaria 19 to 22 days after planting. Eggs were distributed among four holes (approximately $2 \mathrm{~cm}$ deep) around the base of the plant and covered with soil. There were seven replicate pots per hybrid and nematode species. Treatments were completely randomized on a single bench in a greenhouse where soil temperatures varied between 20 and $35^{\circ} \mathrm{C}$.

Nematode eggs were extracted from the millet and corn roots 58 to 60 days after inoculation by the following method. The entire root system of a single plant was cut into approximately $5-\mathrm{cm}$ pieces, placed in a 1-liter flask, and agitated for $4 \mathrm{~min}$ in a $1 \% \mathrm{NaOCl}$ solution (7). Eggs were collected and rinsed with tap water on nested 150 - and $25-\mu \mathrm{m}$ pore sieves, and counted using a dissecting microscope.

Statistical analysis. Factorial analysis of variance (ANOVA) was used to determine the effect of pearl millet hybrid and nematicide on grain yield, numbers of $M$. incognita second-stage juveniles (J2), Paratrichodorus sp., and leaf blight severity. The stubby-root nematode Paratrichodorus sp. was present at low densities at the start of the study, but increased to potentially damaging densities in 1999 . Nematode numbers were transformed by square root before analysis. Regression analysis was used to determine whether there was a relationship between grain yield and at planting densities of either $M$. incognita or Paratrichodorus sp. for each year. Only data from hybrids showing a positive yield increase in nematicidetreated plots $($ HGM-100, $112 \times 115,113 \times$ $115,111 \times 114,109 \times 117$, and $111 \times 117$ ) were used for the regression analysis. To determine whether other factors were associated with grain yields, data from the experimental hybrids were pooled, and Pearson's correlation coefficients were calculated for leaf blight severity, days to anthesis, and plant height for each year by nematicide combination. The relationship between grain yield and leaf blight severity was determined with regression analysis, followed by a $t$ test to determine whether the decline in grain yield (i.e., the slope) differed between nematicide-treated and control plots. For the greenhouse experiment, factorial ANOVA was used to determine the effect of hybrid and nematode species on nematode reproduction. Means from the field and greenhouse experiments were separated using Fisher's LSD test. Pearl millet hybrids were considered resistant if final numbers of $\mathbf{J} 2$ or eggs were less than the susceptible standard hybrid HGM-100 ( $P \leq 0.05)$. All data were analyzed using the Statistical
Analysis System (version 7.0, SAS Institute Inc, Cary, NC).

\section{RESULTS}

Field experiment. Application of 1,3-D reduced $(P<0.0001)$ at planting densities of $M$. incognita $\left(\mathrm{J} 2 / 150 \mathrm{~cm}^{3}\right)$ from 13 in the control plots to 1 in the treated plots in 1998, and from 553 to 52 in 1999. This suppression of the nematode population persisted throughout the season. After harvest, the number of $J 2 / 150 \mathrm{~cm}^{3}$ of soil was lower $(P<0.001)$ in $1,3-\mathrm{D}$ plots than in the control plots (11 versus 94 in 1998 and 120 versus 506 in 1999). Nematode densities were low and not different among pearl millet hybrids after harvest in 1998; however, at planting in 1999, densities were greater than after harvest in 1998 and differed $(P=0.03)$ among pearl millet hybrids (Table 1). The effect of hybrid on nematode density was also apparent after harvest in $1999(P<0.0001)$. In plots not treated with nematicide, hybrids with 114 and 117 as the pollinator had fewer $\mathrm{J} 2 / 150$ $\mathrm{cm}^{3}$ of soil than did HGM-100 both at the beginning and end of the season in 1999. Only one hybrid with 115 as the pollinator had fewer numbers of nematodes than HGM-100, but this difference was only observed after harvest in 1999. At planting and after harvest in 1999, there was an interaction between nematicide treatment and pearl millet hybrid $(P<0.02$ at planting and $P<0.0002$ after harvest). Despite this interaction, the trends in nematode resistance relative to HGM-100 were similar in 1,3-D-treated and control plots after harvest, except for hybrid $107 \times 115$ which was not different from HGM-100 in the treated plots.

Densities of the stubby-root nematode Paratrichodorus sp. were relatively low in 1998 and moderate to high in 1999 (Table

Table 2. Soil densities of Paratrichodorus sp. at planting (Pi) and after harvest (Pf) of pearl millet hybrids during two growing seasons

\begin{tabular}{|c|c|c|c|c|}
\hline \multirow[b]{3}{*}{ Hybrid } & \multicolumn{4}{|c|}{ Nematodes $/ 150 \mathrm{~cm}^{3 \mathrm{a}}$} \\
\hline & \multicolumn{2}{|c|}{1998} & \multicolumn{2}{|c|}{1999} \\
\hline & $\mathbf{P i}$ & $\mathbf{P f}$ & $\mathbf{P i}$ & $\mathbf{P f}$ \\
\hline HGM-100 & 6 & 8 & 86 & 91 \\
\hline $107 \times 115$ & 4 & 28 & 77 & 62 \\
\hline $109 \times 115$ & 3 & 15 & 78 & 100 \\
\hline $111 \times 115$ & 6 & 1 & 57 & 107 \\
\hline $112 \times 115$ & 7 & 13 & 43 & 56 \\
\hline $113 \times 115$ & 5 & 10 & 46 & 79 \\
\hline $111 \times 114$ & 7 & 5 & 51 & $30 * \mathrm{~b}$ \\
\hline $112 \times 114$ & 2 & 9 & 70 & $43^{*}$ \\
\hline $113 \times 114$ & 3 & 15 & 59 & 65 \\
\hline $106 \times 117$ & 0 & 6 & 123 & $35^{*}$ \\
\hline $108 \times 117$ & 0 & 13 & 122 & $29^{*}$ \\
\hline $109 \times 117$ & 1 & 4 & 68 & $46^{*}$ \\
\hline $111 \times 117$ & 0 & 6 & 76 & $45^{*}$ \\
\hline $112 \times 117$ & 3 & 6 & 63 & $32 *$ \\
\hline
\end{tabular}

${ }^{a}$ Soil samples collected 9 July (Pi) and 8 October (Pf) 1998, 10 June (Pi) and 21 September (Pf) 1999. Nematode densities are the mean of 10 plots (five treated with 1,3-dichloropropene and five untreated controls).

${ }^{\mathrm{b}}$ Densities of Paratrichodorus within a column followed by an asterisk are different from HGM-100 Paratrichodorus sp. per $150 \mathrm{~cm}^{3}$ of soil were greater at planting in 1999 than after harvest in 1998. Soil densities of Paratrichodorus sp. were lower $(P<$ 0.0004 ) in plots treated with $1,3-\mathrm{D}$ than in control plots early in the season of 1998 (1 versus 5 per $150 \mathrm{~cm}^{3}$ ) and 1999 (16 versus 129 per $150 \mathrm{~cm}^{3}$ ) but were similar after harvest, and they differed $(P<0.0001)$ among hybrids only after harvest in 1999 (Table 2). All but one hybrid with 114 or 117 as the pollinator had lower densities of Paratrichodorus sp. than HGM-100 $(P<$ 0.05 ), while hybrids with 115 as the pollinator were not different from HGM-100. There was no interaction between nematicide treatment and hybrid on densities of Paratrichodorus sp.

Grain yield was generally greater in 1999 than in 1998 (Table 3). Averaged across hybrids and nematicide treatments, yields were $3,211 \pm 101 \mathrm{~kg} / \mathrm{ha}$ (mean $\pm \mathrm{SE}$ ) and 4,193 $\pm 220 \mathrm{~kg} / \mathrm{ha}$ in 1998 and 1999 , respectively. In 1998, the nematicide 1,3-D had no effect on grain yield; however, in 1999 , yields were greater $(P<0.0001)$ in nematicide-treated plots than in control plots. Averaged across hybrids, grain yields in 1999 were $4,625 \mathrm{~kg} / \mathrm{ha}$ in plots treated with 1,3-D and 3,761 $\mathrm{kg} / \mathrm{ha}$ in control plots. Grain yields differed $(P<0.0001)$ among pearl millet hybrids in both 1998 and 1999. Moreover, there was an interaction $(P=0.04)$ between hybrid and nematicide treatment in 1999. Yields of some hybrids were greater in 1,3-D-treated than in control plots, while the yields of other hybrids were unaffected by nematicide treatment (Table 3). Yield increases in 1999 from the nematicide treatment were unrelated to the relative susceptibility of a hybrid to $M$. incognita reproduction. For hybrids that had greater
2). Similar to $M$. incognita, numbers of $(P \leq 0.05)$.

- 
yields in plots treated with 1,3-D than in control plots, there was an inverse correlation between densities of both $M$. incognita $\mathrm{J} 2 \quad(r=-0.29 ; \quad P=0.02)$ and Paratrichodorus sp. $(r=-0.32 ; P=0.01)$ at planting and grain yield in 1999 but not in 1998.

Leaf blight was less severe in 1998 than Pearl millet hybrids in plots treated with the nematicide 1,3-D had more severe leaf blight symptoms than hybrids in control plots in both years $(P<0.01)$. Averaged in 1999 averaging 3 and 18\%, respectively.

across all hybrids, severity ratings in the treated versus control plots were 3.5 versus 3.3 in 1998 and 19.6 versus 16.8 in 1999. Pearl millet hybrids differed $(P<0.01)$ in leaf blight severity in both years (Table 4). Hybrid HGM-100 and hybrids with pollinator 115 were among the most resistant to leaf blight, while hybrids with pollinators 114 and 117 were among the most susceptible to the disease. There was no interaction between nematicide treatment and hybrid on the severity of leaf blight in either year.

Table 3. Grain yield of pearl millet hybrids in plots treated with the nematicide 1,3-dichloropropene (1,3-D) and plots not treated (control)

\begin{tabular}{|c|c|c|c|}
\hline \multirow[b]{2}{*}{ Hybrid } & \multirow[b]{2}{*}{ Treatment } & \multicolumn{2}{|c|}{ Yield (kg/ha) } \\
\hline & & 1998 & 1999 \\
\hline \multirow[t]{2}{*}{ HGM-100 } & $1,3-\mathrm{D}$ & 3,366 & 6,410 \\
\hline & Control & 3,662 & $4,895^{* a}$ \\
\hline \multirow[t]{2}{*}{$107 \times 115$} & $1,3-\mathrm{D}$ & 3,655 & 3,362 \\
\hline & Control & 3,351 & 3,064 \\
\hline \multirow[t]{2}{*}{$109 \times 115$} & $1,3-\mathrm{D}$ & 2,707 & 6,046 \\
\hline & Control & 2,495 & 5,935 \\
\hline \multirow[t]{2}{*}{$111 \times 115$} & $1,3-\mathrm{D}$ & 3,351 & 5,336 \\
\hline & Control & 3,607 & 4,823 \\
\hline \multirow{2}{*}{$112 \times 115$} & $1,3-\mathrm{D}$ & 4,124 & 5,235 \\
\hline & Control & 4,005 & $3,097 *$ \\
\hline \multirow[t]{2}{*}{$113 \times 115$} & $1,3-\mathrm{D}$ & 4,479 & 6,548 \\
\hline & Control & 3,579 & $3,284 *$ \\
\hline \multirow{2}{*}{$111 \times 114$} & $1,3-\mathrm{D}$ & 3,351 & 5,015 \\
\hline & Control & 3,607 & $4,318 *$ \\
\hline \multirow[t]{2}{*}{$112 \times 114$} & $1,3-\mathrm{D}$ & 3,089 & 3,784 \\
\hline & Control & 2,745 & 3,204 \\
\hline \multirow[t]{2}{*}{$113 \times 114$} & $1,3-\mathrm{D}$ & 2,902 & 3,270 \\
\hline & Control & 2,800 & 2,940 \\
\hline \multirow[t]{2}{*}{$106 \times 117$} & $1,3-\mathrm{D}$ & 3,537 & 4,873 \\
\hline & Control & 3,641 & 4,532 \\
\hline \multirow[t]{2}{*}{$108 \times 117$} & $1,3-\mathrm{D}$ & 2,508 & 3,558 \\
\hline & Control & 3,000 & 3,311 \\
\hline \multirow[t]{2}{*}{$109 \times 117$} & $1,3-\mathrm{D}$ & 2,545 & 4,475 \\
\hline & Control & 2,804 & $3,760 *$ \\
\hline \multirow[t]{2}{*}{$111 \times 117$} & $1,3-\mathrm{D}$ & 2,863 & 4,011 \\
\hline & Control & 2,960 & $2,864 *$ \\
\hline \multirow{2}{*}{$112 \times 117$} & $1,3-\mathrm{D}$ & 2,669 & 2,823 \\
\hline & Control & 2,514 & 2,625 \\
\hline
\end{tabular}

${ }^{a}$ Yields from control plots followed by an asterisk are different from yields in plots treated with 1,3$\mathrm{D}(P \leq 0.05)$.

Table 4. Severity of leaf blight caused by Pyricularia grisea on pearl millet hybrids in 1998 and 1999

\begin{tabular}{llc}
\hline & \multicolumn{2}{c}{ Leaf blight severity $(\boldsymbol{\%})^{\mathbf{a}}$} \\
\cline { 2 - 3 } Hybrid & $\mathbf{1 9 9 8}$ & $\mathbf{1 9 9 9}$ \\
\hline HGM-100 & 0.5 & 2.9 \\
$107 \times 115$ & $2.0^{* \mathrm{~b}}$ & $17.1^{*}$ \\
$109 \times 115$ & $5.3^{*}$ & 3.1 \\
$111 \times 115$ & 1.4 & 3.4 \\
$112 \times 115$ & $1.7^{*}$ & 3.6 \\
$113 \times 115$ & $1.7^{*}$ & 3.1 \\
$111 \times 114$ & $3.0^{*}$ & $19.9^{*}$ \\
$112 \times 114$ & $4.9^{*}$ & $17.8^{*}$ \\
$113 \times 114$ & $4.0^{*}$ & $27.2^{*}$ \\
$106 \times 117$ & $3.1^{*}$ & 6.0 \\
$108 \times 117$ & $4.9^{*}$ & $40.5^{*}$ \\
$109 \times 117$ & $5.3^{*}$ & $23.7^{*}$ \\
$111 \times 117$ & $4.7^{*}$ & $47.6^{*}$ \\
$112 \times 117$ & $5.4^{*}$ & $39.3^{*}$ \\
LSD $(P=0.05)$ & 1.0 & 8.4 \\
\hline
\end{tabular}

${ }^{a}$ Percentage of foliage infected or necrotic on 28 August 1998 and 17 August 1999. Percentages are the means of 10 plots (five treated with 1,3-dichloropropene and five untreated controls).

${ }^{\mathrm{b}}$ Disease severities within a column followed by an asterisk are different from HGM-100 $(P \leq 0.05)$.
Grain yield was negatively correlated with leaf blight severity in the experimental pearl millet hybrids (Fig. 2), but not with anthesis date or plant height; therefore, adjustment of severity values for differences in hybrid maturity was not necessary. Although the severity of leaf blight was less in 1998 than in 1999, there appeared to be a greater reduction in yield from the disease in 1998 (i.e., a greater negative slope). Within a year, the rate of yield reduction with increasing leaf blight severity was similar in plots treated with 1,3-D and control plots (i.e., similar slopes).

Greenhouse experiment. The number of eggs produced by $M$. arenaria was similar between the two trials; however, the number of eggs produced by $M$. incognita was substantially greater in trial 2 than in trial 1 (Fig. 1). In both trials, there was an interaction between hybrid and nematode species $(P<0.0001)$. This interaction was primarily due to the differential reproduction of the two nematodes on corn. Reproduction of $M$. incognita on the two corn hybrids was similar to or slightly greater than on HGM-100, whereas, reproduction of $M$. arenaria was greater on HGM-100 than on the two corn hybrids (Fig. 1). All of the experimental millet hybrids supported less reproduction of $M$. incognita and $M$. arenaria than did HGM-100. The number of nematode eggs per pot was similar among experimental hybrids except for hybrid $120 \times 114$ and $126 \times 103$. In the first trial, $M$. arenaria produced more eggs in hybrid $120 \times 114$ than in four other hybrids; however, in the second trial, this difference was not observed. In trial 2, reproduction of $M$. incognita and $M$. arenaria was greater on hybrid $126 \times 103$ than on any other experimental hybrid but was less than on HGM-100.

\section{DISCUSSION}

In the field experiment, densities of $M$. incognita and Paratrichodorus sp. in plots planted to pearl millet hybrids with 114 and 117 as the male pollinator were lower than in plots planted to hybrids with 115 as the pollinator or to HGM-100. For M. incognita, these differences were apparent at planting time (spring) and after harvest (fall) in 1999, but not after harvest in 1998. Generally, soil densities of Meloidogyne spp. peak in the late summer or early fall and decline over winter in annual crops (12); however, densities of both $M$. incognita and Paratrichodorus sp. were higher in the spring of 1999 than in the previous fall. Apparently, our ability to detect nematodes in the soil was lower in the fall of 1998 than during the spring of 1999. The reasons for this lower detection efficiency are unclear. Perhaps soil moisture and temperature were not conducive for egg hatch resulting in fewer numbers of vermiform stages, or human error resulted in poor extraction efficiencies from soil. 
Results from the field experiments indicated that pearl millet hybrids with 114 or 117 as the male pollinator were resistant to reproduction of $M$. incognita and Paratrichodorus sp. We confirmed this resistance to $M$. incognita in the greenhouse experiment. Moreover, we showed that pollinators designated 101, 102, and 103 also conferred resistance to this nematance to $M$. incognita were also resistant to $M$. arenaria. Although reproduction of both Meloidogyne spp. on $126 \times 103$ was less than on HGM-100, this hybrid appears to be only moderately resistant when compared to the other experimental millet hybrids. No hybrids with 115 as the pollinator were included in the greenhouse experiment; therefore, we do not know whether these hybrids are resistant or susceptible to $M$. arenaria. Resistance of pearl millet hybrids to Paratrichodorus sp. was observed in only one field season (fall of 1999) and was not confirmed in the greenhouse. tode. All pearl millet hybrids with resis-

M. incognita reproduced as well on the pearl millet hybrid HGM-100 as on corn, which is considered a good host for reproduction of this nematode $(4,19)$. In the first greenhouse trial, reproduction of $M$. incognita was considerably less than expected on the corn hybrids. At inoculation levels of 8,000 eggs, this nematode typically produces 1 to $4 \times 10^{5}$ eggs per root system after 2 months rather than the $3 \times 10^{4} \mathrm{eggs}$ per root system produced in the first trial (4). The lower level of $M$. incognita reproduction in trial 1 may have been due to low viability of the nematode inoculum. All experimental millet hybrids were poor hosts for reproduction of $M$. incognita relative to the corn hybrids. Except for millet hybrid $126 \times 103, M$. arenaria reproduced similarly on the experimental hybrids as it did on corn, which is considered a poor host for reproduction of this nematode $(4,19)$. The pearl millet hybrids HGM-100 and $126 \times 103$, on the other hand, were better hosts for reproduction of $M$. arenaria than were the corn hybrids.
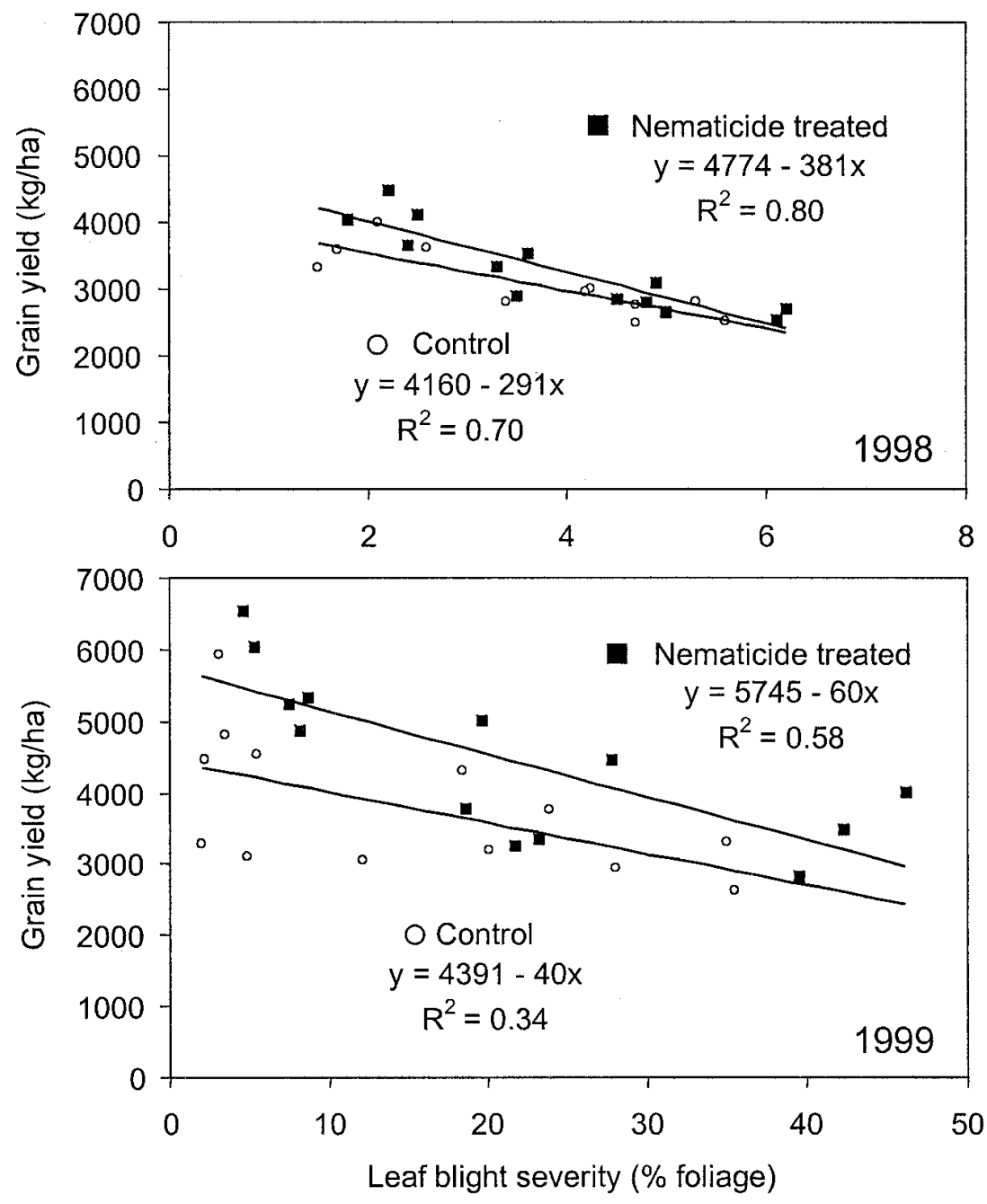

Fig. 2. Relationship between grain yield and leaf blight severity among experimental pearl millet hybrids grown in Tifton, Georgia in 1998 and 1999. Leaf blight severity was greater in 1999 than in 1998 (x-axis). Each point is the mean of five replicates. The slopes of the lines from plots treated with the nematicide 1,3-dichloropropene (1,3-D) are not different from the slopes of the lines from the nontreated control plots.
Although the nematicide 1,3-D reduced densities of $M$. incognita $\mathrm{J} 2$ and Paratrichodorus sp. at planting time in both 1998 and 1999, grain yields were greater in nematicide-treated plots compared to control plots only in 1999. Densities of these nematodes at planting were much lower in 1998 than in 1999, and perhaps were not great enough in 1998 to reduce grain yield of pearl millet. Grain yields of many resistant and susceptible millet hybrids were similar in nematicidetreated and control plots in 1999 indicating some level of tolerance to damage by $M$. incognita and/or Paratrichodorus sp. Johnson et al. (10) suggested that HGM-100 was tolerant to damage from $M$. incognita because minimal galling is produced in infected root systems. In this study, yields of HGM-100 were lower in control than in nematicide-treated plots; however, this yield reduction may have been due to parasitism by $M$. incognita, Paratrichodorus sp., or a combination of both species. The effect of Paratrichodorus sp. on pearl millet is unknown. In Georgia, the damage threshold for this nematode in corn is 40 individuals per $100 \mathrm{~cm}^{3}$ (or $60 / 150 \mathrm{~cm}^{3}$ ) of soil (3). At planting in 1999, densities of Paratrichodorus sp. ranged from 70 to 236 individuals per $150 \mathrm{~cm}^{3}$ of soil in control plots and 6 to 30 individuals per $150 \mathrm{~cm}^{3}$ soil in the nematicide-treated plots. For those hybrids that showed a positive yield response to the nematicide treatment, grain yields increased with decreasing densities of both Paratrichodorus sp. and M. incognita J2 in 1999 but not in 1998.

There was a slight increase in leaf blight severity in plots treated with the nematicide 1,3-D in both 1998 and 1999. This increase was likely the result of more vigorous plant growth and associated denser canopy in the treated than in the control plots. In a similar situation, an increase in stem rot of peanut caused by Sclerotium rolfsii in plots treated with the insecticide/nematicide aldicarb was thought to result from a denser canopy cover early in the season due to suppression of thrips and nematodes (16). The nematicide 1,3-D had a greater effect on leaf blight severity in 1999 than in 1998, possibly because there were higher nematode populations and significant yield losses in the control than in the nematicide-treated plots. The pearl millet hybrid HGM-100, which contains a single dominant gene for resistance to $P$. grisea derived from $P$. glaucum subsp. monodii (5), was the most resistant to leaf blight. Although less consistent than HGM-100, several hybrids with 115 as the pollinator had less severe leaf blight symptoms than hybrids with 114 or 117 as the pollinator suggesting some resistance to this disease in inbred 115.

The severity of leaf blight was less in 1998 than in 1999 nevertheless, there was a much greater reduction in yield associated with leaf blight in 1998. The difference in 
response between the 2 years suggests that other factors in addition to leaf blight were contributing to the disease severity/yield loss relationship. In 1998, 70 and $80 \%$ of the variation in grain yield was explained by leaf blight severity in the control and nematicide-treated plots, respectively, whereas in 1999, 34 and $58 \%$ of the variation was explained by disease severity in control and treated plots. Nematode damage was a confounding factor in 1999. In this year, populations of both $M$. incognita and Paratrichodorus sp. were large and associated with yield loss in some pearl millet hybrids. Two hybrids, $112 \times 115$ and $113 \times 115$, which had relatively low leaf blight severity in 1999, suffered yield losses from nematode damage in the control plots.

Hybrids with pollinator 115 were susceptible to $M$. incognita, but resistant to leaf blight caused primarily by $P$. grisea, whereas hybrids with pollinators 114 and 117 were resistant to $M$. incognita and $M$. arenaria but susceptible to leaf blight. Resistance to both nematodes and leaf blight in the experimental pearl millet hybrids appears to be conferred by dominant genes in the male pollinator because all the experimental hybrids were derived from genetically similar sister lines of Tift $99 \mathrm{~A}_{1}$. We have shown that both pathogens can reduce grain yield of pearl millet. Therefore, new hybrids intended for use in the southeastern United States should contain genes for resistance to both Meloidogyne spp. and $P$. grisea. Pearl millet hybrids with resistance to Meloidogyne spp. will be compatible in rotation with cotton, peanut, and vegetable crops because nematode populations will not increase to damaging levels on the millet, thus reducing the yield of the succeeding susceptible crop.

\section{ACKNOWLEDGMENTS}

We thank T. L. Hilton, D. L. Clements, W. H. Wilson, F. Cheek, J. Merriman, and J. Golden for their assistance in data collection and crop management; and R. N. Gates and R. F. Davis for helpful suggestions during preparation of this manuscript.

\section{LITERATURE CITED}

1. Burton, G. W., Wallace, A. T., and Rachie, K. O. 1972. Chemical composition and nutritive value of pearl millet (Pennisetum typhoides (Burm.) Stapf and E.C. Hubbard) grain. Crop Sci. 12:187-188.

2. Cook, R. and Evans, K. 1987. Resistance and tolerance. Pages 179-231 in: Principles and Practice of Nematode Control in Crops. R. H. Brown, and B. R. Kerry, eds. Academic Press, New York.

3. Davis, R. F., Bertrand, P., Gay, J. D., Baird, R. E., Padgett, G. B., Brown, E. A., Hendrix, F. F., and Balsdon, J. A. 1996. Guide for interpreting nematode assay results. Circular 834 . Cooperative Extension Service, University of Georgia, Athens.

4. Davis, R. F. and Timper, P. 2000. Resistance in selected corn hybrids to Meloidogyne arenaria and $M$. incognita. Suppl. J. Nematol. 32:633-640.

5. Hanna, W. W. 1993. Registration of pearl millet parental lines Tift 8677 and $A_{1} / B_{1}$ Tift $90 \mathrm{D}_{2} \mathrm{E}_{1}$. Crop Sci. 33:1119.

6. Hill, G. M. and Hanna, W. W. 1990. Nutritive characteristics of pearl-millet grain in beefcattle diets. J. Animal Sci. 68:2061-2066.

7. Hussey, R. S. and Barker, K. R. 1973. A comparison of methods of collecting inocula for Meloidogyne spp., including a new technique. Plant Dis. Rep. 57:1025-1028.

8. Jenkins, W. R. 1964. A rapid centrifugalflotation technique for separating nematodes from soil. Plant Dis. Rep. 48:692.

9. Johnson, A. W., Burton, G. W., and Wright, W. C. 1977. Reactions of sorghum-sudangrass hybrids and pearl millet to three species of Meloidogyne. J. Nematol. 9:352-353.

10. Johnson, A. W., Hanna, W. W., and Dowler, C. C. 1995. Effects of irrigation, nitrogen, and a nematicide on pearl millet. J. Nematol. 27:571-574.

11. Johnson, A. W., Hanna, W. W., and Wilson, J. P. 1999. Identification of nematode resistance in pearl millet grain hybrids. Int. Sorghum Millets Newsl. 40:58-60.

12. Norton, D. C. 1978. Ecology of Plant Parasitic Nematodes. Wiley \& Sons, New York.

13. Payne, W. A., Wendt, C. W., and Lascano, R. J. 1990. Root zone water balance of three low-input millet fields in Niger, West Africa. Agron. J. 82:813-819.

14. Smith, R. L., Hoveland, C. S., and Hanna, W. W. 1989. Water stress and temperature in relation to seed germination of pearl millet and sorghum. Agron. J. 81:303-305.

15. Smith, R. L., Jensen, L. S., Hoveland, C. S., and Hanna, W. W. 1989. Use of pearl millet sorghum, and triticale grain in broiler diets. J. Prod. Agric. 2:78-82.

16. Timper, P., Minton, N. A., Johnson, A. W., Brenneman, T. B., Culbreath, A. K., Burton, G. W., Baker, S. H., and Gascho, G. J. 2001 Influence of cropping systems on stem rot (Sclerotium rolfsii), Meloidogyne arenaria, and the nematode antagonist Pasteuria penetrans in peanut. Plant Dis. 85:767-772.

17. Wilson, J. P., Casper, H. H., and Wilson, D. M. 1995. Effect of delayed harvest on contamination of pearl millet grain with mycotoxin-producing fungi and mycotoxins. Mycopathologia 132:27-30.

18. Wilson, J. P. and Gates, R. N. 1993. Forage yield losses in hybrid pearl millet due to leaf blight caused primarily by Pyricularia grisea. Phytopathology. 83:739-743.

19. Windham, G. L. and Williams, W. P. 1987. Host suitability of commercial corn hybrids to Meloidogyne arenaria and M. incognita. Ann. Appl. Nematol. (Suppl. J. Nematol. 19) 1:13-16. 